\title{
Tinjauan Elevasi Puncak Bangunan Seawall di Pantai Galesong Utara
}

\author{
Indra Mutiara ${ }^{1, a}$ \\ ${ }^{1}$ Jurusan Teknik Sipil, Politeknik Negeri Ujung Pandang, Jalan Perintis Kemerdekaan Km. 10, Makassar, 90245 Indonesia \\ indramutiara@poliupg.ac.id
}

\begin{abstract}
This study aims to review the use of vertical datum and determine the elevation of seawall constructions based on the sea level design. The sea level design used as a vertical reference is MSL and LWS. The elevation of the seawall construction from the two references above then compared to the elevation of the seawall construction listed in the as built drawing document during construction. The MSL value is obtained from the tidal analysis by using Doodson method based on direct observation for 39 hours, while the LWS value is obtained by taking into account the position of the range of tide at Tide Station in Makassar. Seawall elevation is obtained by terrestrial measurements using the Total Station by measuring the height of the top position of the seawall construction against the sea level design through the Bench Mark. The seawall top elevation data collection is done every one meter along 274 meters. The results obtained from measuring seawall construction elevation are + $\mathbf{2 , 2 5 1}$ meters if using reference to MSL and +2,911 meters if using a reference to $L W S$, while the elevation in the as built drawing document is $+4,000$ meters unknown what vertical reference is used as a reference.
\end{abstract}

Keywords-Seawall; Elavation; MSL, LWS

\footnotetext{
Abstrak-Penelitian ini bertujuan untuk meninjau penggunaan datum vertikal dan mengetahui elevasi bangunanseawall berdasarkan muka air laut rencana. Muka air laut rencana yang digunakan sebagai acuan vertikal adalah MSL dan LWS. Elevasi bangunan seawall dari kedua referensi tersebut selanjutnya dibandingkan terhadap elevasi bangunan seawall yang tercantum pada gambar rencana saat konstruksi.Nilai MSL diperoleh dari analisis pasut metode Doodson berdasarkan pengamatan langsung selama 39 jam, sedangkan nilai LWS diperoleh dengan memperhitungkan posisi tunggang pasut pada Stasiun Pasut di Makassar. Elevasi seawall diperoleh dengan pengukuran teristris menggunakan alat Total Station dengan mengukur beda tinggi puncak bangunan seawall terhadap muka air lautrencana melalui titik BM di darat. Pengambilan data elevasi puncak seawall dilakukan tiap satu meter sepanjang 274 meter. Hasil yang diperoleh dari pengukuruan elevasi bangunan seawall yaitu $+2,251$ meter jika menggunakan acuan terhadap MSL dan $+2,911$ meter jika menggunakan acuan terhadap LWS, sedangkan elevasi digambar rencana sebesar $+4,000$ metertidak diketahui referensi vertikal apa yang digunakan sebagai referensi.
}

Kata Kunci-Seawall; Elavasi; MSL, LWS

\section{Pendahuluan}

Pantai Galesong Utara di Desa Sampulungan, Kecamatan Galesong Utara, Kabupaten Takalar, Propinsi Sulawesi Selatan merupakan salah satu wilayah pantai yang mengalami abrasi cukup parah. Abrasi yang terjadi diakibatkan gelombang pasang yang terjadi pada musim barat pada bulan Desember sampai dengan bulan April. Selama lima tahun terakhir, abrasi telah menyebabkan kemunduran garis pantai yang mengancam kehidupan dan penghidupan masyarakat setempat.

Penanggulangan yang telah dilakukan oleh pemerintah untuk menangani abrasi tersebut adalah pembangunan tanggul laut (seawall). Tipe seawall yang dibuat adalah tipe Curved Seawall yaitu seawall yang mencerminkan bentuk gelombang ketika bergerak menuju daratan. Desainnyaakan menghilangkan dampak dari gelombang dengan membelokkannya keatas, menjauh dari bagian bawah struktur. Dinding ini biasanya terbuat dari beton dan dirancang untuk mengurangi gerusan/penghilangan sedimen dari sekitar struktur yang akan melemahkan seawall di dasar dinding [1].

Berdasarkan gambar rencana, bangunan seawall yang ada di pantai Galesong Utara memiliki elevasi rencana sebesar $+4,000$ meter. Tetapi tidak diperoleh informasi mengenai acuan vertikal untuk memperoleh nilai $+4,000$ meter tersebut [2]. 


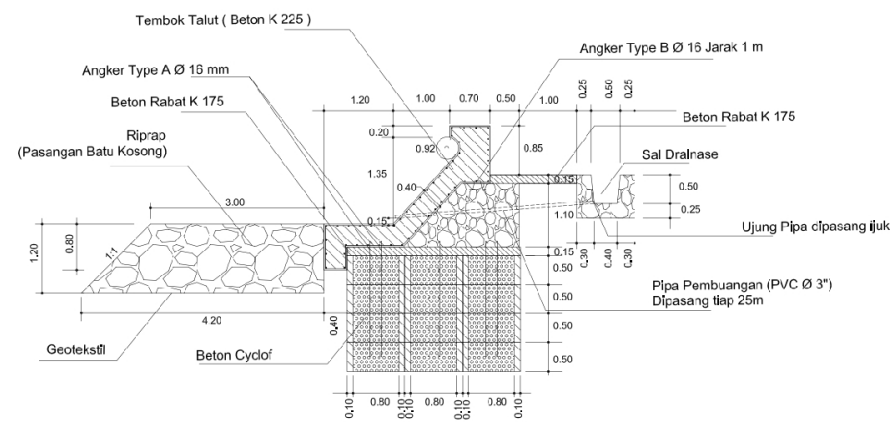

Gambar 1. Tembok Laut tipe Curved Sea Wal

Muka air laut yang umumnya digunakan sebagai acuan nilai elevasi bangunan di sekitar pantai adalah MSL (Mean Sea Level) atau muka air laut rerata yang diperoleh dari hasil pengamatan pasang surut air laut.

MSL tidak hanya merupakan titiknol bagi ordinat dari komponen harmonik pasut, tetapijuga disebut datum acuan standar bagi elevasi daratan.Jika gaya pasut tidak ada, maka permukaan laut tanpagangguan pasut itu adalah MSL [3].

Muka air laut yang juga sering digunakan sebagai acuan nilai elevasi adalah LWS (Low Water Level) atau muka air surut terendah yang diambil dari elevasi muka air surut yang paling surut/terendah selama periode 15 atau 29 hari pengamatan pasut.

Pada penelitian ini akan ditinjau elevasi puncak bangunan seawalldengan mengacu pada nilai MSL dan pada nilai LWS.

\section{Metode Penelitian}

\section{A. Analisis DataPasang Surut}

Pada penelitian ini dilakukan pengamatan pasang surut secara langsung di lapangan selama 39 jam secara terus menerus dengan interval pencatatan tiap 1 jam. Pengamatan dilakukan dengan cara memasang rambu pasang surut (peilschaal) berupa balok ukuran $6 \times 12 \mathrm{~cm}$ panjang 3,5 meter dipasang tegak. Pada balok tersebut ditempel bacaan berskala dengan ukuran 10x300 cm dengan skala bacaan tiap $2 \mathrm{~cm}$. Pemasangan peilschaal dilakukan ketika kondisi air di depan bangunan seawall dalam keadaan surut, dengan tujuan untuk memudahkan pemasangan peilschaal di lapangan. Lokasi pemasangan peilschaal harus selalu terendam oleh air laut agar elevasi muka air laut pada skala bacaan dapat diamati. Pengamatan dimulai pada tanggal 24 April 2018 pukul
06:00 WITA hingga tanggal 25 April 2018 pukul 20:00 WITA.

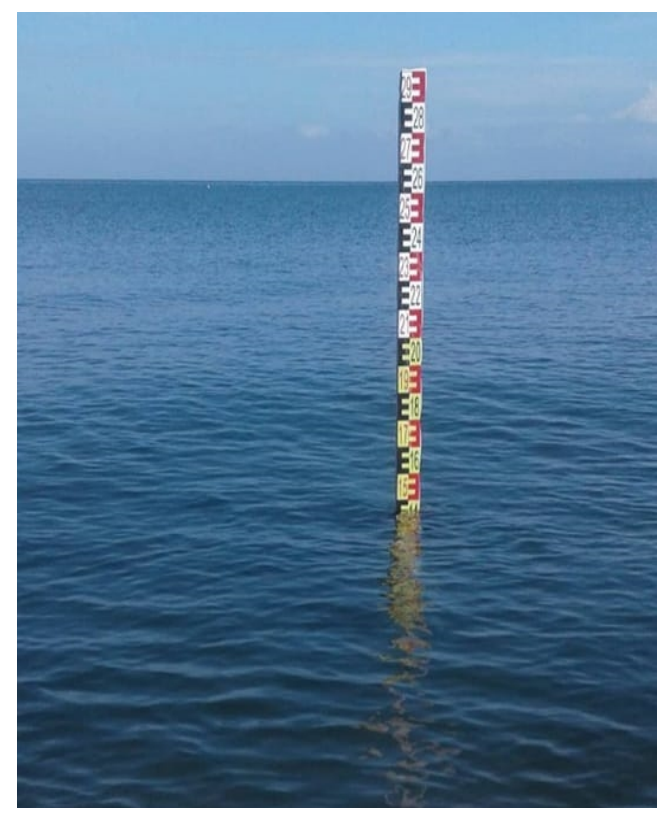

Gambar 2. Peilschaal pasang surut

Dari data pengamatan pasang surut diperoleh pencatatan elevasi muka air pada suatu waktu yang terdiri dari tiga bacaan yaitu elevasi muka air tertinggi, elevasi muka air yang sering terjadi (tengah) dan elevasi muka air terendah. Selanjutnya ketiga bacaan tersebut dilakukan pembobotan untuk mendapatkan bacaan tunggal pada suatu waktu pengamatan. Elevasi muka air tengah diberi bobot sebesar $60 \%$, sedangkan elevasi muka air tertinggi dan terendah diberi bobot masingmasing sebesar $20 \%$.

Data pengamatan 39 jam yang tiap data per jam nya sudah diubah menjadi bacaan tunggal, selanjutnya dianalisis menggunakan metode Doodson untuk mengeliminasi nilai muka air laut rerata (MSL).

Metode filter Doodson digunakan untuk menghitung muka laut rata-rata untuk periode observasi yang pendek, yakni 39 jam. Maksud dari pemakaian filter tersebut adalah untuk menghilangkan energi pasut pada pasut harian (diurnal) dan pasut yang mempunyai konstanta harmonik tinggi [4].

Dalam hal ini filter Doodson mempunyai batasan $1>t>19$. Dengan $F(t)=(2,1,1,2,0,1,1,0,2,0,1,1,0$, $1,0,0,1,0,1)$. Mengingat bentuk filter tersebut adalah simetri, maka $F(t)=F(-t)$. Rumus yang dipakai dalam metode ini adalah: 


$$
X_{T}=\frac{1}{3} \sum_{d=-1}^{d=1} F(d) H(T+d), d \neq 0
$$

dimana : $\quad \mathrm{X}_{\mathrm{T}} \quad=$ muka laut rerata

$$
\begin{array}{ll}
\mathrm{H}(\mathrm{t}) & =\text { elevasi muka laut } \\
\mathrm{T} & =\text { jam } 12.00
\end{array}
$$

Nilai LWS diperoleh dari pencatatan realtime pada stasiun pasut otomatis milik BIG (Badan Informasi dan Geospasial) di Makassar. Dengan asumsi posisi bidang datar imajiner MSL di lokasi seawall dan MSL di stasiun pasut adalah sama, selanjutnya nilai LWS tersebut diukur terhadap nilai MSL di lokasi bangunan seawall dibangun.

\section{B. Pengukuran Elevasi Seawall}

Titik di darat yang menyimpan elevasi terhadap muka air laut rencana biasanya berupa titik BM. Di sekitar lokasi seawall tidak diperoleh adanya titik BM, sehingga pada penelitian ini dilakukan pembuatan titik BM di darat sebanyak satu buah. Ukuran BM adalah 20x20x23 $\mathrm{cm}$, dipasang pada lokasi yang mantap, mudah terlihat dan aman dari pengaruh air laut (tidak terendam, tidak terkena hempasan gelombang).

Pengikatan MSL ke BM dapat dilakukan dengan pengukuran sipat datar (Waterpass) atau biasa disebut leveling, dari pengukuran tersebut didapat beda tinggi BM terhadap MSL. Dengan demikian didapat elevasi $\mathrm{BM}$ dengan ketinggian dari MSL, BM ini kemudian dapat dijadikan acuan untuk bangunan-bangunan disekitar pantai [5].

Selanjutnya elevasi seawall terhadap MSL dan LWS dapat dilakukan dengan mengukur elevasi puncak seawall terhadap BM. Alat yang digunakan pada pengukuran ini adalah Total Station.

\section{Hasil dan Pembahasan}

\section{A. Elevasi Muka Air Rencana}

Elevasi muka air laut hasil pengamatan 39 jam dianalisis dengan menggunakan metode Doodson

\begin{tabular}{|c|c|c|c|}
\hline No. & Faktor (fi) & $\mathrm{A}(\mathrm{cm})$ & fi $\times A(\mathrm{~cm})$ \\
\hline 1 & 1 & 124,4 & 124,4 \\
\hline 2 & 0 & 139,8 & 0,0 \\
\hline 3 & 1 & 145,8 & 145,8 \\
\hline 4 & 0 & 152,8 & 0,0 \\
\hline 5 & 0 & 151,6 & 0,0 \\
\hline 6 & 1 & 144,0 & 144,0 \\
\hline 7 & 0 & 140,0 & 0,0 \\
\hline 8 & 1 & 131,0 & 131,0 \\
\hline 9 & 1 & 126,0 & 126,0 \\
\hline 10 & 0 & 126,4 & 0,0 \\
\hline 11 & 2 & 131,2 & 262,4 \\
\hline 12 & 0 & 140,4 & 0,0 \\
\hline 13 & 1 & 142,6 & 142,6 \\
\hline 14 & 1 & 146,2 & 146,2 \\
\hline 15 & 0 & 142,0 & 0,0 \\
\hline 16 & 2 & 129,0 & 258,0 \\
\hline 17 & 1 & 110,4 & 110,4 \\
\hline 18 & 1 & 85,8 & 85,8 \\
\hline 19 & 2 & 71,6 & 143,2 \\
\hline 20 & 0 & 62,0 & 0,0 \\
\hline 21 & 2 & 58,0 & 116,0 \\
\hline 22 & 1 & 64,0 & 64,0 \\
\hline 23 & 1 & 78,4 & 78,4 \\
\hline 24 & 2 & 94,6 & 189,2 \\
\hline 25 & 0 & 114,6 & 0,0 \\
\hline 26 & 1 & 125,6 & 125,6 \\
\hline 27 & 1 & 143,6 & 143,6 \\
\hline 28 & 0 & 148,0 & 0,0 \\
\hline 29 & 2 & 144,6 & 289,2 \\
\hline 30 & 0 & 138,4 & 0,0 \\
\hline 31 & 1 & 132,0 & 132,0 \\
\hline 32 & 1 & 129,0 & 129,0 \\
\hline 33 & 0 & 125,6 & 0,0 \\
\hline 34 & 1 & 123,2 & 123,2 \\
\hline 35 & 0 & 131,4 & 0,0 \\
\hline 36 & 0 & 137,8 & 0,0 \\
\hline 37 & 1 & 137,8 & 137,8 \\
\hline 38 & 0 & 141,0 & 0,0 \\
\hline 39 & 1 & 143,4 & 143,4 \\
\hline \multicolumn{3}{|c|}{ Duduk Tengah Sementara (DTS) } & 116,4 \\
\hline
\end{tabular}
sebagaimana disajikan pada tabel berikut:
Tabel 1.Perhitungan MSL Metode Doodson

Dari Tabel1 diatas diperoleh nilai elevasi MSL berdasarkan metode Doodson sebesar $+116,4 \mathrm{~cm}$ atau $+1,164$ meter dari nol peilschaal terpasang.

\section{B. Hubungan antara BM ke MSL}

MSL merupakan bidang datar imajiner yang merupakan kedudukan muka air laut jika tidak ada pengaruh pasang surut. Jika peilschaal berubah kondisi atau rusak/hilang baik disebabkan kesengajaan atau karena ganggunan alam maka angka $+1,164$ meter yang merupakan bidang acuan elevasi vertikal tersebut tidak dapat ditelusuri keberadaaannya, sehingga nilai MSL tersebut harus diikatkan terhadap suatu titik di darat.

Titik di darat yang menyimpan elevasi terhadap MSL biasanya berupa titik BM. Elevasi BM diperoleh dengan melakukan pengukuran beda tinggi antara peilschaal dan BM di darat menggunakan alat ukur waterpass.Dengan menggunakan MSL sebagai acuan \pm 0.00 meter, maka diperoleh elevasi BM sebesar $+1,773$ meter dari MSL. 


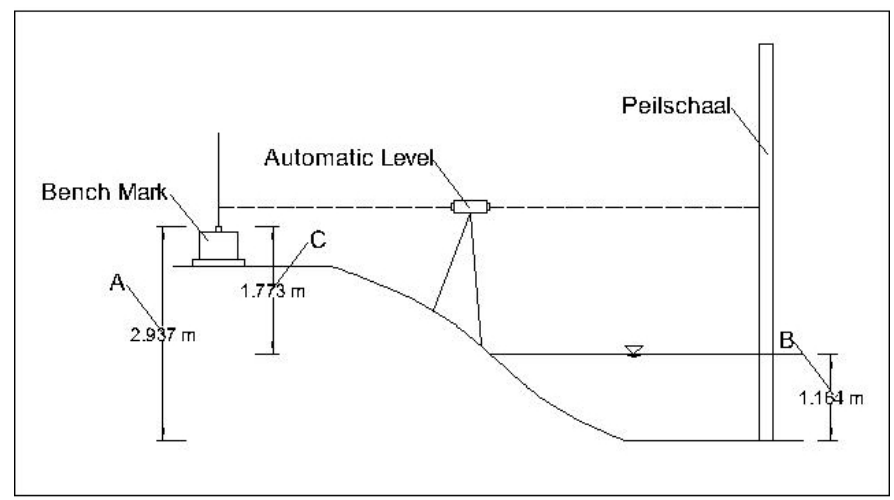

Gambar 3. Sketsa Levelling BM-Peilschaal

Keterangan gambar :

a. $\Delta \mathrm{H}$ BM-Peilschaal $=2,937$ meter

b. Elevasi MSL di peil = 1,164 meter

c. Elevasi $\mathrm{BM}=(\mathrm{A})-(\mathrm{B})$

$$
\begin{aligned}
& =2,937-1,164 \text { meter } \\
& =1,773 \text { meter dari MSL. }
\end{aligned}
$$

\section{Pengukuran Elevasi Seawall}

Elevasi BM di darat sudah mengacu kepada MSL sebagai acuan elevasi vertikal. Selanjutnya elevasi seawall terhadap MSL dapat dilakukan dengan mengukur elevasi puncak seawall terhadap BM. Pengukuran elevasi puncak seawall dilakukan dengan mengukur beda tinggi antara puncak seawall terhadap BM di darat. Alat yang digunakan pada pengukuran ini adalah Total Station.

Puncak seawall yang diukur sepanjang 273 meter dengan titik-titik pengambilan data tiap satu meter dengan menggunakan reflector less. Data yang diperoleh dari hasil pengukuran elevasi puncak seawall sebanyak 274 data.

Dari data pengukuran yang dilakukan, diperoleh elevasi seawall berkisar antara 2,160 meter sampai dengan 2,311 meter terhadap MSL.

\section{Analisis Statistik Data Elevasi Seawall}

Data elevasi seawall yang diperoleh sebanyak 274 data. Dari data tersebut selanjutnya dihitung nilai rereta, varians dan standar deviasinya.

Kualitas data pengukuran tersebut dapat dinilai dari besaran standar deviasinya. Standar deviasi adalah nilai statistik yang digunakan untuk menentukan bagaimana sebaran data dalam sampel, dan seberapa dekat titik data individu ke nilai rata-rata dari sampel.Sebuah standar deviasi dari kumpulan data sama dengan nol menunjukkan bahwa semua nilai-nilai dalam himpunan tersebut adalah sama. Sebuah nilai deviasi yang lebih besar akan memberikan makna bahwa titik data individu jauh dari nilai rata-rata.

Tabel 2. Hasil Perhitungan parameter statistik Data Elevasi Seawall

\begin{tabular}{ccc}
\hline No. & Parameter Statistik & Nilai \\
\hline 1 & Rerata $(\bar{X})$ & $2,251 \mathrm{~m}$ \\
2 & Varians $\left(\mathrm{S}^{2}\right)$ & $0.001 \mathrm{~m}^{2}$ \\
3 & Standar Deviasi (S) & $0,032 \mathrm{~m}$ \\
\hline
\end{tabular}

Elevasi hasil peninjauan menunjukan nilai rerata elevasi seawall sebesar $+2,251$ meter dari MSL dengan nilai standar deviasi (simpangan baku) sebesar 0,032 meter. Nilai standar deviasi yang kecil dan mendekati nol menunjukkan sebaran data yang diambil sudah akurat dan tidak berbeda jauh dengan nilai reratanya.

\section{E. Tinjauan Elevasi Seawall terhadap LWS}

Elevasi seawall yang tercantum pada gambar rencana sebesar $+4,00$ meter sangat berbeda jauh dengan nilai elevasi seawall hasil peninjauan $(+2,251$ meter) dengan selisih sebesar 1,749 meter.

Perbedaan yang besar tersebut mungkin disebabkan karena perbedaan acuan elevasi muka air rencana yang digunakan sebagai acuan elevasi vertikal. Sebagai bahan perbandingan, maka dilakukan perhitungan nilai elevasi seawall dengan acuan elevasi vertikal MSL dan acuan elevasi vertikal LWS. Nilai LWS diperoleh dari pencatatan realtime pada stasiun pasut otomatis milik BIG (Badan Informasi dan Geospasial) di Makassar. Dengan asumsi posisi bidang datar imajiner MSL di lokasi seawall dan MSL di stasiun pasut adalah sama, selanjutnya nilai LWS tersebut diukur terhadap nilai MSL di lokasi bangunan seawall dibangun. 


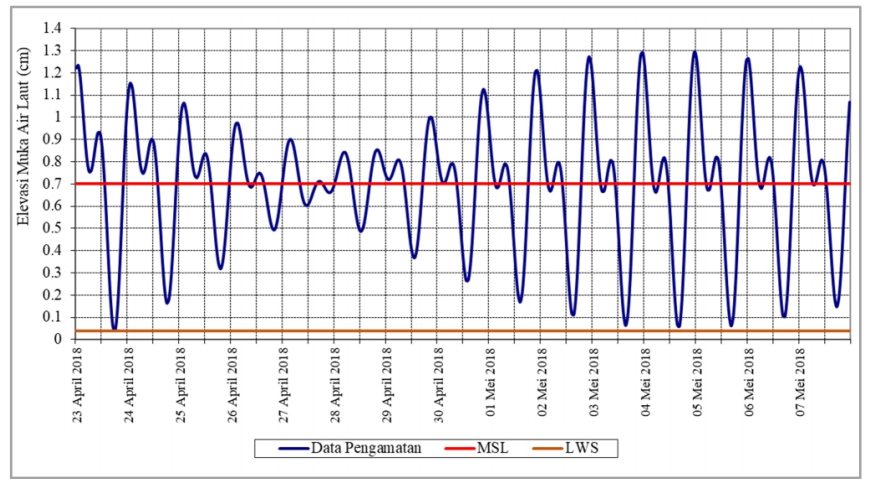

Gambar 4. Grafik data pasut pencatatan otomatis Stasiun Pasut BIG lokasi Makassar selama 15 hari

Berdasarkan Gambar 4 diatas menunjukkan nilai MSL sebesar 0,699 meter dan nilai LWS sebesar 0,039 meter. Sehingga selisih MSL-LWS adalah 0,660 meter. Dengan asumsi posisi bidang datar imajiner MSL di lokasi seawall dan MSL di stasiun pasut adalah sama, selanjutnya elevasi seawall terhadap LWS diperoleh dengan menambahkan nilai $+2,251$ meter dengan selisih MSL-LWS (0,660 meter), sehinggan elevasi seawall adalah $(+2,251)+(0,660)=+2,911$ meter dari LWS.

Tabel 3. Perbandingan elevasi seawall

\begin{tabular}{ccc}
\hline No. & Peninjauan & Gambar Rencana \\
\hline 1 & $+2,251 \mathrm{~m} \mathrm{MSL}$ & \\
2 & $+2,911 \mathrm{~m} \mathrm{LWS}$ & $+4,00$ meter \\
& & (unknown vertical datum)
\end{tabular}

Berdasarkan Tabel 3 diatas diperoleh data bahwa nilai elevasi puncakseawall terhadap MSL sebesar $+2,251$ meter, sedangkan elevasi puncak seawall terhadap LWS sebesar $+2,911$ meter. Dari dua parameter referensi vertikal yang digunakan tidak ada satu pun nilai yang mendekati nilai elevasi puncak seawall yang direncakan pada gambar yaitu sebesar $+4,000$ meter.

Pembangunan seawall dilakukan secara bertahap per segmen. Elevasi puncak seawall biasanya mengacu pada segmen seawall yang sudah dibangun sebelumnya. Nilai elevasi sebesar $+4,000$ meter didasarkan pada informasi elevasi pada segmen seawall yang sudah ada sebelumnya. Kebenaran elevasi tersebut dapat ditelusuri jika ada BM yang dijadikan referensi (menyimpan nilai elevasi rencana).

Setelah melakukan penyelidikan di lapangan dan mencari informasi yang berkaitan dengan pembangunan seawall di pantai Galesong Utara, ternyata di lokasi tidak ditemukan titik pengikat atau BM sebagai titik referensi sehingga nilai elevasi $+4,000$ meter pada gambar rencana tidak diketahui referensi vertikal apa yang digunakan di lapangan,apakah terhadap MSL atau terhadap LWS. Meskipun demikian elevasi puncak seawall di lapangan sudah mengakomodasi run-up gelombang yang terjadi, sehingga dari sisi kinerja bangunan seawall di pantai Galesong Utara sudah mampu melindungi area di belakangnya yang merupakan kawasan permukiman. Namun dari sisi informasi aset bangunan nilai elevasi perlu dilakukan peninjauan.

\section{Kesimpulan dan Saran}

Berdasarkan hasil dan pembahasanpada penelitian ini dapat disimpulkan sebagai berikut:

1. Tinjauan nilai elevasi puncak seawall terhadap MSL menghasilkan nilai sebesar $+2,251$ meter.

2. Tinjauan nilai elevasi puncak seawall terhadap LWSmenghasilkan nilai sebesar $+2,911$ meter.

Saran untuk keberlanjutan dari penelitian ini adalah sebagai berikut :

1. MSL yang diperoleh pada penelitian ini didasarkan pada MSL pengukuran pasang surut di lapangan selama 39 jam. Hasil yang lebih baik jika dilakukan pengamatan pasang surut di lapangan minimal 15 hari.

2. LWS yang diperoleh pada penelitian ini didasarkan pada asumsi posisi bidang datar imajiner MSL di lokasi seawall dan MSL di stasiun pasut adalah sama, selanjutnya elevasi seawall terhadap LWS diperoleh dengan menambahkan nilai MSL dengan selisih MSLLWS. Dengan melakukan pengamatan pasang surut di lapangan minimal 15 hari sebagaimana pada poin (1) diatas, nilai selisih MSL-LWS akan lebih baik.

3. Aset bangunan pengaman pantai harusnya memiliki elevasi terhadap muka air laut rencana, maka diperlukan suatu titik tetap (BM) di darat yang berguna untuk menyimpan elevasi terhadap muka air laut rencana. Pihak yang berwenang sebaiknya memasang BM pada lokasi seawall di pantai Galesong Utara. 


\section{Daftar Pustaka}

\section{Ucapan Terima Kasih}

Ucapan terima kasih diberikan kepada Balai Besar Wilayah Pompengan Jeneberang dan PT. Yudha Nusantara Indah,yang banyak memberikan kontribusi positif bagi penyelesaian penelitian ini.
[1] J. Salgado, "Types of Seawalls", 25 April 2017, [Online]. Tersedia: https://sciencing.com/types-seawalls-8394254.html [Diakses: 24September 2018].

[2] PT. Yudha Nusantara Indah, "Gambar : Mutual Check Awal (0\%)", 2017.

[3] I. Mutiara, dan A.H. Muhiddin, "Pengamatan Pasang Surut untuk Penentuan Datum Elevasi Ketinggian di Pantai Desa Parak, Kecamatan Bonto Matene, Kabupaten Selayar, Provinsi Sulawesi Selatan," SPERMONDE,vol. 2, no. 2,pp.44-46, September 2016.

[4] Suyarso,"Muka Laut Rata-rata dan Aplikasinya dalam Jaring Geodesi", Pasang Surut. Jakarta: LIPI, 1989, 193-195

[5] I. Mutiara, "Penentuan Elevasi BM Lokal terhadap MSL Hasil Pengamatan Pasut dan terhadap MSL yang Diukur dari TTG 024," PHINISI, vol. 11, no. 1, pp.33-42, April 2016. 